\title{
EVALUACIÓN DE LA CAPACIDAD DE CARGA EN LOS SENDEROS DE TURISMO DE LUCIÉRNAGAS, NANACAMILPA, TLAXCALA
}

\section{EVALUATION OF THE CARRYING CAPACITY OF FIREFLY TOURISM TRAILS IN NANACAMILPA, TLAXCALA}

\author{
Zazil Ha Mucui Kac García-Trujillo ${ }^{1}$, Silvia X. Almeraya-Quintero² ${ }^{2}$ Lenin G. Guajardo-Hernández², Jorge A. Torres-Pérez ${ }^{3}$
}

\author{
${ }^{1}$ Instituto Tecnológico de la Zona Maya (zazilgarcia@gmail.com). ${ }^{2}$ Colegio de Postgraduados \\ (xoalmeraya@gmail.com, glenin@colpos.mx). ${ }^{3}$ Universidad Autónoma Chapingo \\ (jorgeatorresperez@yahoo.com.mx).
}

\begin{abstract}
RESUMEN
La conservación de ecosistemas forestales a través del ecoturismo es una de las opciones que contempla beneficios sociales, ambientales y económicos, cuando un destino ecoturístico está en desarrollo es importante hacer estudios que generen información para planificar a largo plazo el manejo ambiental y preservar las condiciones necesarias para un desarrollo sustentable. En los últimos tres años, se ha incrementado el número de visitantes a la zona, En 2015 el flujo de visitantes fue de 71 636, registrando un incremento del 27\% respecto a 2014, En 2016 se registró un flujo de 90000 turistas, reflejando un incremento de $26 \%$ respecto a 2015. El objetivo fue calcular la capacidad de carga en los senderos de avistamiento de la luciérnaga en Nanacamilpa, Tlaxcala para determinar el número de turistas adecuado para la infraestructura existente basada en la metodología propuesta por Cifuentes. Esta metodología permite determinar cuantas personas pueden visitar un sitio sin dañar el hábitat. En la temporada 2016 se recibió un promedio de 1200 visitantes al día y el estudio arrojó un máximo permisible de 466 visitantes por día en todos los senderos, esto indica que se está sobrepasando la capacidad de resiliencia del ecosistema. Se encontró que la cantidad de visitantes actuales sobrepasa la capacidad de carga óptima poniendo en riesgo la conservación del fenómeno natural e impactando socialmente por el número de visitantes que requieren servicios locales para los cuales la infraestructura actual no es suficiente.
\end{abstract}

Palabras clave: capacidad de carga turística, impacto ambiental, santuario de la luciérnaga, turismo sustentable.

\footnotetext{
* Autor responsable $*$ Author for correspondence.

Recibido: junio, 2018. Aprobado: diciembre, 2018.

Publicado como ARTÍCULO en ASyD 18: 127-143. 2021.
}

\begin{abstract}
The conservation of forest ecosystems through ecotourism is one of the options that provides social, environmental and economic benefits. When an ecotourism destination development, it is important to carry out studies that generate information for long term-planning of environmental management and to preserve the conditions necessary for sustainable development. In the last three years, the number of visitors to the area has increased. In 2015, the flow of visitors was 71636 , an of increase $27 \%$ compared to 2014. In 2016, a flow of 90000 tourists was recorded, reflecting an increase of $26 \%$ over 2015 . The objective was to calculate the carrying capacity of the for firefly viewing trails in Nanacamilpa, Tlaxcala, to determine the appropriate number of tourists for the existing infrastructure based on the methodology proposed by Cifuentes. This methodology allows determining how many people can visit a site without damaging the habitat. In the 2016 season, an average of 1200 visitors per day were received, and the study showed a maximum of 466 visitors allowed per day in all trails, indicating that the resilience of the ecosystem is being exceeded. It was found that the current number of visitors exceeds the optimal carrying capacity, putting at risk the conservation of the natural phenomenon and having a social impact because of the number of visitors who require local services for which the current infrastructure is not sufficient.
\end{abstract}

Key words: tourism carrying capacity, environmental impact, firefly sanctuary, sustainable tourism.

\section{INTRODUCTION}

he conservation of natural resources,
especially forests and rainforests, has become
a worldwide preoccupation, primarily 


\section{INTRODUCCIÓN}

$\mathrm{L}$ a conservación de los recursos naturales principalmente los bosques y selvas, se ha concional, principalmente por los servicios ambientales que proporciona que son indispensables para la vida humana. El Plan de Aplicación de las Decisiones de la Cumbre Mundial sobre el Desarrollo Sostenible (ONU, 2002) propone el ecoturismo como uno de los pilares del desarrollo y mitigación del cambio climático. El plantear el desarrollo del turismo dentro del paradigma de la sustentabilidad, hoy es una necesidad, ya que ha dejado de ser un complemento de las economías para erigirse en una de las actividades más importantes del planeta y en muchos casos, el único modelo que tienen muchos países en su proceso de adecuación a la economía mundial, dominada por los servicios (Virgen, 2014).

El ecoturismo se desarrolla en ecosistemas naturales, en muchos casos bosque y selvas que cuentan con escenarios propicios para atraer a visitantes que buscan un acercmiento con la naturaleza, México se ubica en el lugar número 12 en cuanto a superficie forestal mundial (Organización de las Naciones Unidas para la Alimentación y la Agricultura [FAO], 2005); sin embargo también fue uno de los países que registraron la mayor disminución en el área de bosques primarios en los últimos 20 años (Organización de las Naciones Unidas para la Alimentación y la Agricultura $[\mathrm{FAO}], 2010)$. En este sentido, la pérdida de los ecosistemas forestales significa impactos negativos en el cambio climático y menores oportunidades para el desarrollo de proyectos ecoturístios que ayuden a conservar los bosque y selvas.

Los bosques son hábitat de innumerables especies de plantas y animales vitales para la sustentabilidad del ecosistema, un ejemplo claro son los santuarios de la mariposa monarca en Michoacán y el santuario de las luciérnagas en Tlaxcala, estas especies necesitan forzosamente la conservación del área para que puedan permanecer, reproducirse y brindar los servicios ecosistémicos. El reconocimiento tácito de los servicios ambientales que prestan la conservación in situ de muchos recursos de uso común, ha creado un nuevo debate dentro de este paradigma de la conservación, (Álvarez-Icaza, 2005). En este caso, el turismo sustentable representa una opción para la conservación de of Implementation on Sustainable Development (ONU, 2002) proposes ecotourism as one of the pillars of development and mitigation of climate change. Suggesting the development of tourism within the paradigm of sustainability is a necessity today, since it has ceased to be a complement of economies to become one of the most important activities in the world, and in many cases, the only model that many countries have in their adaptation process to the global economy, which is dominated by services (Virgen, 2014).

Ecotourism develops in natural ecosystems, in many cases forests and rainforests have propitious sceneries that attract visitors seeking contact with nature. Mexico ranks number 12 with regard to world forest surface (Food and Agriculture Organization of the United Nations, FAO, 2005). However, it was also one of the countries that showed the largest decrease in area of primary forests in the last 20 years (FAO, 2010). In this sense, the loss of forest ecosystems entails negative impacts on climate change and less opportunities for the development of ecotourism projects that help to conserve the forests and rainforests.

Forests are habitats of countless plant and animal species that are vital for the ecosystem's sustainability; a clear example are the monarch butterfly sanctuaries in Michoacán and the firegly sancturary in Tlaxcala. These species unavoidably need the conservation of the area in order to remain, reproduce and provide ecosystem services. The tacit recognition of environmental services provided by in situ conservation of many resources of common use has created a new debate within this conservation paradigm (Álvarez-Icaza, 2005). In this case, sustainable tourism represents an option for the conservation of forest habitats, generating income for the communities and protecting the environmental services provided by the forest.

According to Antinori and Rausser (2010), Mexico is first place globally in natural forest area under communal property that is commercially viable, which is why this type of property is of special significance for climate change mitigation efforts. In addition to this, forests areas are favorable to the development of complementary activities such as ecotourism, which is why there is great potential for the integral exploitation of natural areas. 
hábitats boscosos generando ingresos a las comunidades y protegiendo los servicios ambientales que provee el bosque.

De acuerdo a Antinori y Rausser (2010), México tiene el primer lugar a nivel mundial en extensión de bosques naturales comercialmente viable bajo propiedad comunal, por lo que este tipo de propiedad tiene especial significado para los esfuerzos de mitigación del cabio climático. Aunado a esto, los bosques son áreas propicias para el desarrollo de actividades complementarias como el ecoturismo, por lo que se cuenta con un gran potencial para el aprovechamiento integral de las áreas naturales.

El ecoturismo representa una oportunidad para la conservación del ecosistema forestal y una oportunidad para sensibilizar a los visitantes en el cuidado, respeto y uso adecuado de los recursos naturales, y a la vez es una fuente de empleo y desarrollo económico generando ingresos a las comunidades y protegiendo los servicios ambientales que provee el bosque.

El turismo ha sido motor del desarrollo de muchas culturas, sin embargo, esto no significa que se dé un impacto positivo en las comunidades, de acuerdo a Arnais y César (2004), el desarrollo sustentable es una de las tareas difíciles de lograr, ya que cada sector de la sociedad tiene su propia perspectiva de lo que es o debe ser este modelo de desarrollo. Este se debe basar en al menos cuatro bases, lo ecológico, lo social, lo cultural y lo económico.

La Organización Mundial del Turismo (OMT, 2017) define el turismo sostenible como "El turismo que tiene plenamente en cuenta las repercusiones actuales y futuras, económicas, sociales y medioambientales para satisfacer las necesidades de los visitantes, de la industria, del entorno y de las comunidades anfitrionas". Este tipo de turismo está siendo impulsado por las organizaciones internacionales como una forma de desarrollo sostenible.

El año 2017 fue declarado por la Asamblea General de las Naciones Unidas como el Año Internacional del Turismo Sostenible para el Desarrollo, destacando que este es una oportunidad única para ampliar la contribución del sector del turismo a los tres pilares de la sostenibilidad (económico, social y del medio ambiente); así como para aumentar la conciencia sobre las verdaderas dimensiones de un sector que se suele infravalorar. Esta decisión se suma al reconocimiento por parte de los líderes mundiales en la Conferencia de las Naciones Unidas sobre el
Ecotourism represents an opportunity for conservation of the forest ecosystem and an opportunity to sensitize visitors to the care, respect and proper use of natural resources and at the same time it is a source of employment and economic development, generating income for communities and protecting the environmental services that provided by the forest.

Tourism has been the motor of development of many cultures, although this does not mean that there is a positive impact in the communities. According to Arnaiz and César (2004), sustainable development is one of the most difficult tasks to achieve, as each sector of society has its own perspective of what this development model is or should be. It must be based on at least four foundation: the ecological, the social, the cultural and the economic.

The United Nations World Tourism Organization (OMT, 2017) defines sustainable tourism as "Tourism that takes full account of its current and future economic, social and environmental impacts, addressing the needs of visitors, the industry, the environment and host communities". This type of tourism is being fostered by international organizations as a form of sustainable development.

The year 2017 was declared by the General Assembly of the United Nations as the International Year of Sustainable Tourism for Development, stressing that it is a unique opportunity to extend the contribution of the tourism sector to the three pillars of sustainability (economic, social and environmental); as well as to increase awareness about the true dimensions of a sector that tends to be undervalued. This decision adds to the recognition by world leaders durign the United Nations Conference on Sustainable Development that took place in Rio de Janeiro, Brazil, on June $20^{\text {th }}$ to $22^{\text {nd }}$, 2012, that a well-conceived and well-managed tourism can contribute to the three dimensions of sustainable development, create employment and generate commercial opportunities (OMT, 2015). Sustainable tourism, in addition to providing income to local inhabitants, is one of the most efficient ways of natural resources conservation and allows the communities with forest areas to diversify the activities based on the environment.

Calculating the carrying capacity is precisely what will help a tourist destination to maintain an equilibrium between the pillars of sustainability, to 
Desarrollo Sostenible que tuvo lugar en Río de Janeiro, Brasil del 20 al 22 de junio de 2012, de que el turismo bien concebido y bien gestionado puede contribuir a las tres dimensiones del desarrollo sostenible, crear empleo y generar oportunidades comerciales (OMT, 2015). El turismo sostenible además de proporcionar ingresos a los pobladores locales es una de las formas más eficientes de conservación de los recursos naturales y permite que las comunidades con áreas boscosas diversifiquen las actividades basadas en el medioambiente.

El cálculo de la capacidad de carga es justamente lo que va a ayudar a un destino turístico a mantener un equilibrio entre los pilares de la sustentabilidad, para lograr de esta forma una estabilidad entre el desarrollo medioambiental, económico y el social al evitar aglomeración de usos de suelo, excesos poblacionales y deterioro de recursos naturales (Mc-Coy y Sosa, 2016).

Guerrero (2010) afirma que una de las mayores limitaciones que tiene el estudio del ecoturismo es la falta de investigación acerca de las realidades existentes en los proyectos que se llevan a cabo.

El surgimiento del turismo comunitario se relaciona con varios aspectos: en primer lugar, la mayoría de las comunidades rurales han registrado un deterioro de su calidad de vida debido a la crisis del sector agropecuario y las limitaciones de las políticas públicas para atender la problemática, por lo cual se hizo evidente la necesidad de explorar actividades alternativas para complementar el ingreso y empleo de la población rural (Palomino, Gasca y López, 2015).

Nanacamilpa proviene de la palabra nanacamilpan en lengua náhuatl. Esta a su vez, derivada de nanaca de nanacatl, que significa hongo; así como mil de milli, vocablo que indica sementera o campo sembrado; y finalmente pan cuya partícula implica en o sobre de, de tal modo que nanacamilpa quiere decir "campo sobre los hongos" o en la "sementera de los hongos" (INAFED, 2016).

En el municipio de Nanacamilpa se presenta el fenómeno natural del cortejo de la luciérnaga durante los meses de junio a septiembre, espectáculo que atrae a turistas. Hasta la fecha, no se ha analizado el nivel de impactos ambientales que el turismo ha traído, por lo que es importante identificar los elementos del ambiente que están siendo afectados por los turistas y que la actividad se convierta no solo en una opción económica, sino de conservación para el hábitat. therefore achieve stability between environmental, economic and social development by avoiding the agglomeration of land uses, population excesses, and deterioration of natural resources (Mc-Coy and Sosa, 2016).

Guerrero (2010) states that one of the greatest limitations that the study of ecotourism faces is the lack of research about the existing realities in the projects that are being implemented.

The emergence of community tourism relates to several aspects: first and foremost, the mayority of, most rural communities have recorded a deterioration of their quality of life due to the crisis of the agriculture and livestock sector and the limitations of public policies to address the problem, which made evident the need to explore alternative activities to complement the income and employment of the rural population (Palomino, Gasca and López, 2015).

Nanacamilpa comes from the word nanacamilpan in the Náhuatl language. In turn, it comes from nanaca of nanacatl, which means fungus; as well as from mil of milli, term that indicates cropland or planted field; and finally, pan which implies on or of, so that nanacamilpa means "field on fungi" or "cropland of fungi" (INAFED, 2016).

In the municipality of Nanacamilpa there is the natural phenomenon of firefly courtship during the months of June to September, spectacle that attracts tourists. Until now, the level of environmental impact caused by tourism has not been analyzed, so it is important to identify the elements of the environment that are being affected by tourists in order for the activity to become not just an economic option, but rather one for habitat conservation.

The fireflies responsible for the spectacle in the area of Nanacamilpa correspond to a species that was unknown to science until recently, which is endemic (that is, it is not found anywhere else in the world) to the conifer forests where the tourist activities take place. The name of this species is Macrolampis palaciosi and belongs to the coleoptera family called Lampyridae (Zaragoza-Caballero, 2012). According to studies by the Zoology Department of the Biology Institute at Universidad Nacional Autónoma de México (UNAM), in the year 2012, out of the 32 species of fireflies found in Mexico of the Macrolampis genus, the one that is found in Nanancamilpa, Macrolampis palaciosi, does not coincide with any of the known ones; therefore, it is considered as a new 
Las luciérnagas responsables del espectáculo en la zona de Nanacamilpa corresponden a una especie hasta hace poco desconocida para la ciencia, la cual es endémica (es decir, que no se le encuentra en ninguna otra parte del mundo), de los bosques de coníferas donde se encuentra la zona de actividades ecoturísticas. El nombre de esta especie es Macrolampis palaciosi y pertenece a la familia de coleópteros denominada Lampyridae (Zaragoza-Caballero, 2012). De acuerdo a estudios del Departamento de Zoología, del Instituto de Biología de la Universidad Nacional Autónoma de México (UNAM), en el año 2012, de las 32 especies de luciérnagas registradas en México del género Macrolampis, la que se ubica en Nanancamilpa, Macrolampis palaciosi, no coincide con ninguna de las conocidas, considerada como una nueva especie propia de los ecosistemas de la región. (CONAFOR, 2013)

Las luciérnagas son un grupo de insectos del orden de los coleópteros de la familia Lampyridae, con especies distribuidas en todas las regiones zoogeográficas del mundo, adaptadas a las condiciones ambientales específicas de cada lugar como respuesta a los procesos evolutivos. En el continente Americano, está representada por 1134 especies que pertenecen a 40 géneros. En México, se reconocen 90 especies distribuidas en los diferentes ecosistemas. Estos insectos son muy característicos por la presencia de órganos luminosos, dicha emisión de luz la realizan las larvas como defensa y atracción de presas y los adultos para el cortejo, a lo que se denomina bioluminiscencia. En este proceso se lleva a cabo la oxidación de la luciferina en presencia de la enzima luciferasa, que es producida a intervalos de tiempo, la cual emite una luz brillante sin emitir calor (Méndez y Campos, 2016).

Las mayores poblaciones de luciérnagas se les observa en las áreas boscosas que han tenido poca o nula perturbación por el hombre, así como en donde las condiciones ambientales son favorables para su desarrollo; por otra parte, las actividades relacionadas con el cambio de uso de suelo como son la agricultura, el desmonte y la expansión de zonas urbanas y rurales han propiciado a que el área de distribución se reduzca constantemente, por lo cual es importante mantener el estado de conservación de los bosques para que se garantice la permanencia de esta especie (Méndez y Campos, 2016).

Es una realidad que el turismo está establecido en Nanacamilpa, el objetivo de este estudio es medir la species that belongs to the ecosystems of the region (CONAFOR, 2013).

Fireflies are a group of insects of the coleopteran order, of the Lampyridae family, with species distributed in every zoogeographic region of the world, adapted to the specific environmental conditions of each place as a response of evolutionary processes. In the American continent, it is represented by 1134 species that belong to 40 genera. In Mexico, 90 species are recognized, distributed in different ecosystems. These insects are characterized by the presence of luminous organs, and the light emission called bioluminescence is shown by larvae as defense and attraction of prey and by adults for courtship. In this process, oxidation of luciferin takes place in presence of the luciferase enzyme, which is produced at time intervals, and which emits a bright light without emiting heat (Méndez-Montiel and Campos-Bolaños, 2016).

Most populations of fireflies are found in forest areas that have had little or no disturbance by humans, as well as where environmental conditions are favorable for their development; on the other hand, activities related to the change in land use such as agriculture, clearing and expansion of urban and rural areas have favored for the distribution area to be constantly reduce, which is why it is important to maintain the conservation state of forests in order to guarantee the permanence of this species (Méndez-Montiel and Campos-Bolaños, 2016).

It is a reality that tourism is established in Nanacamilpa. The objective of this study is to measure the carrying capacity on the firefly sighting trails and to propose impact mitigation measures for conservation of the forest ecosystem and the permanence of ecotourism as a form of sustainable development. If the flow of visitors is not controlled, the most likely scenario is that the deterioration of resources will result in the disappearance of the natural phenomenon due to the change in conditions in the habitat necessary for its reproduction.

\section{MATERIALS AND METHODS}

Nanacamilpa is located in the western region of the state of Tlaxcala, and its forest area is 3121.39 ha made up of oyamel, oak and pine; it is characterized 
capacidad de carga en los senderos de avistamiento de luciérnagas y proponer medidas de mitigación de impactos para la conservación del ecosistema forestal y permanencia del ecoturismo como una forma de desarrollo sustentable. Si no se controla el flujo de visitantes lo más probable es que el deterioro de los recursos den como resultado la desaparición del fenómeno natural en la zona por el cambio de las condiciones en el hábitat necesario para su reproducción.

\section{MATERIALES Y MÉTODOS}

Nanacamilpa se localiza al poniente del estado de Tlaxcala, su zona boscosa es de 3121.39 ha compuesta por bosques de oyamel, encino y pino, se caracteriza por su clima templado y húmedo, a una altura de $2800 \mathrm{~m}$ sobre el nivel del mar (Comisión Nacional Forestal [CONAFOR], 2013).

Ubicado en el Altiplano central mexicano a 2,720 metros sobre el nivel del mar, el municipio de Nanacamilpa de Mariano Arista se sitúa en un eje de coordenadas geográficas entre los 19 grados 29 minutos latitud norte y 98 grados 32 minutos longitud oeste. Localizado al poniente del estado de Tlaxcala, el municipio de Nanacamilpa colinda al norte y poniente con el municipio de Calpulalpan, al sur colinda con el estado de Puebla y al oriente se establecen linderos con el municipio de Sanctórum de Lázaro Cárdenas (SEGOB-CEDEMUN, 2001).

La superficie del municipio es de 6809 hectáreas; área que representa el 2.8 por ciento de la superficie total del estado. De este total, 6092 hectáreas, el 89.5 por ciento constituye la superficie de labor, o sea las tierras dedicadas a cultivos anuales o de ciclo corto, frutales y plantaciones. En pastos naturales existía un total de 610 hectáreas dedicadas a la ganadería; 70 hectáreas sólo con bosque o selva; y 37 hectáreas sin vegetación (INAFED, 2016).

El municipio de Nanacamilpa de Mariano Arista cuenta con 6 localidades de más de 100 habitantes y una población de 16640 habitantes, de los cuales $51.16 \%$ son mujeres y $48.84 \%$ hombres y $62.68 \%$ son mayores de 18 años (INEGI, 2010).

\section{Infraestructura turística}

A pesar de que el estado de Tlaxcala no es de los principales destinos turísticos, se caracteriza por recibir visitantes de los estados vecinos. El estado cuenta con by its temperate and humid climate, at an altitude of $2800 \mathrm{~m}$ above sea level (Comisión Nacional Forestal, CONAFOR, 2013).

Located in the Mexican Central High Plateau, at 2720 meters above sea level, the municipality of Nanacamilpa de Mariano Arista is located on an axis of geographic coordinates between 19 degrees 29 minutes latitude North and 98 degrees 32 minutes longitude West. Located in western Tlaxcala, the municipality of Nanacamilpa borders north and west with the municipality of Calpulalpan, south with the state of Puebla, and it borders east with the municipality of Sanctórum de Lázaro Cárdenas (SEGOB-CEDEMUN, 2001).

The surface of the municipality is 6809 hectares; this area represents $2.8 \%$ of the total surface of the state. From this total, 6092 hectares, 89.5\% constitutes the farming surface, that is the lands devoted to annual or short cycle crops, fruit trees and plantations. In natural grasses there was a total of 610 hectares devoted to livestock production; 70 hectares with only forest or rainforest; and 37 hectares without vegetation (INAFED, 2016).

The municipality of Nanacamilpa de Mariano Arista has 6 localities of more than 100 inhabitants and a population of 16640 inhabitants, of which $51.16 \%$ are women and $48.84 \%$ men, and $62.68 \%$ are 18 years or older (INEGI, 2010).

\section{Tourism infrastructure}

Although the state of Tlaxcala is not among the main tourist destinations, it is characterized by receiving visitors from neighboring states. The state has an offer of 335 lodging establishments, of which 121 are hotels, 200 motels and 14 cabins or similar, with a total of 5075 rooms or lodging units. In the year 2015, they received 100033 tourists, of which $99.07 \%$ are national, and there was hotel occupation of $31.2 \%$, far below the national median with an average stay of 1.3 nights. It has 366 establishments of food preparation and service, of which 221 are restaurants, 98 coffee shops, 4 night clubs and 43 bars (SECTUR, 2016).

The municipality of Nanacamilpa has 15 lodging establishments, of which 8 are hotels, 3 motels and 4 cabins or similar, with a total of 165 rooms. Of these establishments, there is only one with one star and another one with two stars; the other 13 are 
una oferta de 335 establecimientos de hospedaje, de los cuales 121 son hoteles, 200 moteles y 14 cabañas o similares, con un total de 5075 cuartos o unidades de hospedaje. En el año 2015 recibieron 100033 turistas, de los cuales $99.07 \%$ son nacionales y una ocupación hotelera de $31.2 \%$ muy por debajo de la media nacional y una estadía promedio de 1.3 noches. Cuenta con 366 establecimientos de preparación y servicios de alimentos de los cuales 221 son restaurantes, 98 cafeterías, 4 centros nocturnos y 43 bares (SECTUR, 2016).

El municipio de Nanacamilpa cuenta con 15 establecimientos de hospedaje, de los cuales 8 son hoteles, 3 moteles y 4 cabañas o similares, con un total de 165 cuartos. De estos establecimientos, solamente hay uno de una estrella y otro de dos estrellas, los trece restantes están clasificados como sin categoría. Las habitaciones con alguna clasificación de estrella son 15. Cuenta con cuatro establecimientos de preparación y servicio de alimentos y bebidas y una agencia de viajes o servicios de reservación (SECTUR, 2016).

El turismo de avistamiento de luciérnagas en el municipio de Nanacamilpa inició en el año 2011 que fue abierto al público para la observación del fenómeno natural. A partir de la promoción turística, diferentes grupos se han organizado para establecer condiciones en los predios para que el turismo pueda observar el fenómeno natural. Para determinar el manejo actual del turismo que llega a Nanacamilpa se realizó un estudio de capacidad de carga.

El análisis de experiencias de aplicación de la capacidad de carga nos ofrece un amplio abanico de posibilidades en la utilización de esta herramienta como referente operacional del desarrollo sustentable, permite la definición de condicionantes y regulaciones respecto de la ubicación, intensidad y tipo de actividades posibles en el territorio, considerando su fragilidad, más que la definición de un límite exacto de uso (Cortés, 2009).

De acuerdo a Vargas, Castillo y Zizumbo (2011) bajo el enfoque de conservación en las zonas turísticas hay una estrecha relación entre el turismo sustentable y la capacidad de carga (Butler, 1980; Mathieson y Wall, 1982; y Saarinen, 2006) a partir de que en un espacio turístico deben existir límites al crecimiento, porque cuando se superan éstos, se pueden afectar los componentes sociales, económicos y naturales quizá de una manera irreversible.

Cifuentes (1999) afirma que la determinación de la capacidad de carga constituye una herramienta de classified as without category. There are 15 rooms with some star classification. It has 4 establishments for preparation and service of foods and beverages, and a travel agency or booking service (SECTUR, 2016).

Tourism for firefly sighting in the municipality of Nanacamilpa began in the year 2011 when it was open to the public for observation of the natural phenomenon. Since the tourism promotion started, different groups have been organized to establish conditions in the plots for tourists to be able to observe the natural phenomenon. In order to determine the current management of tourism that reaches Nanacamilpa, a carrying capacity study was performed.

The analysis of experiences of application of the carrying capacity offers us a broad range of possibilities in the use of this tool as operational referent of sustainable development, it allows the definition of conditions and regulations with regard to the location, intensity and type of activities possible in the territory, considering its fragility, rather than the definition of an exact limit of use (Cortés, 2009).

According to Vargas, Castillo and Zizumbo (2011), using the approach of conservation in tourist areas, there is a close relationship between sustainable tourism and carrying capacity (Butler, 1980; Mathieson and Wall, 1982; Saarinen, 2006), since in a tourist space there should be limits to growth, because when these are exceeded, the social, economic and natural components can be affected, perhaps irreversibly.

Cifuentes (1999) states that to determine the carrying capacity constitutes a planning tool that allows obtaining an approximation to the intensity of use of the areas.

The carrying capacity was calculated to determine the adequate number of tourists for the existing infrastructure based on the methodology proposed by Cifuentes (1992), applied by Puente, Pérez and Solís (2011) in monarch butterfly sighting trails, and by Ibañez (2016) in environmental management units (unidades de manejo ambiental, UMA).

In order to calculate the carrying capacity, the flow of tourists received in the 2016 seasons of 90,000 visitors was taken as a basis. This flow has increased every year causing greater impacts in the area. Table 1 presents the increase of tourists starting in 2014. 
planificación que permite obtener una aproximación a la intensidad de uso de las áreas.

Se calculó la capacidad de carga para determinar el número de turistas adecuado para la infraestructura existente basada en la metodología propuesta por Cifuentes (1992), aplicada por Puente, Pérez y Solís (2011) en senderos de avistamiento de mariposa monarca y por, Ibañez (2016) en unidades de manejo ambiental (UMA).

Para efecto del cálculo de la capacidad de carga se tomó como base el flujo de turista recibidos en la temporada 2016 que fue de 90000 visitantes. Este flujo ha ido aumentando cada año ocasionando mayores impactos en la zona. En el Cuadro 1 se presenta el incremento de turistas a partir de 2014.

La propuesta de Cifuentes (1992) contempla la Capacidad de Carga Física (CCF), Capacidad de Carga Real (CCR), y la Capacidad de Carga Efectiva o permisible (CCE) en donde:

a) Capacidad de Carga Física (CCF) es la relación simple entre el espacio disponible por visitante sin tomar en cuenta factores de protección, comodidad o calidad de la experiencia. Expresa el límite máximo de visitas que puede hacerse a un sitio con espacio definido en un tiempo determinado. La fórmula utilizada fue:

$\mathrm{CCF}=$ Longitud Superficie utilizada $\times$ Persona * No. de veces que el sitio puede ser visitado por una persona el mismo día

La capacidad de carga física (CCF) para cada sendero se calculó con la formula $\mathrm{CCF}=(\mathrm{S} / \mathrm{SP})$ $(\mathrm{NV})$, se presentan las variables utilizadas en el Cuadro 2.

La capacidad de carga física en cada sendero es de 150 personas, esto sin tomar en cuenta la comodidad ni funcionalidad, solamente espacio requerido. La capacidad de carga real (CCR) determina condiciones de comodidad y distancias para brindar

Cuadro 2. Variables para el cálculo de la capacidad de carga física. Table 2. Variables for the calculation of the physical carrying capacity.

\begin{tabular}{llc}
\hline \multicolumn{3}{c}{ Calculo de capacidad de carga física } \\
\hline $\mathrm{S}$ & Longitud de senderos & $300 \mathrm{~m}$ \\
$\mathrm{SP}$ & Superficie usada por visitante & $2 \mathrm{~m}$ \\
$\mathrm{NV}$ & Número de veces visitante por día & 1 \\
$\mathrm{NV}=$ & Hv/tv & 1 \\
$\mathrm{Hv}$ & Horario de visitas & 2 \\
$\mathrm{Tv}$ & Tiempo necesario & 2 \\
\hline
\end{tabular}

Cuadro 1. Flujo anual de turistas en el Municipio de Nanacamilpa de Mariano Arista.

Table 1. Annual flow of tourists in the Municipality of Nanacamilpa de Mariano Arista.

\begin{tabular}{ll}
\hline Año & Turistas \\
\hline 2014 & 56559 \\
2015 & 71636 \\
2016 & 90000 \\
\hline
\end{tabular}

Fuente: elaboración propia con datos del Municipio de Nanacamilpa de Mariano Arista. Source: prepared by authors with data from the Municipality of Nanacamilpa de Mariano Arista.

The proposal by Cifuentes (1992) considers the Physical Carrying Capacity (PCC), Real Carrying Capacity (RCC), and the permissible or Effective Carrying Capacity (ECC) where:

a) The Physical Carrying Capacity (PCC) is the simple relation between the available space per visitor without taking into account factors of protection, comfort or quality of the experience. It expresses the maximum limit of visits that can be made to a site with defined space in a specific time. The formula used was:

PCC $=$ Surface Length Used $\times$ Person ${ }^{*}$ No. of times that the site can be visited by a person on the same day

The Physical Carrying Capacity (PCC) for each trail was calculated with the formula $\mathrm{PCC}=(\mathrm{S} /$ $\mathrm{SP})(\mathrm{NV})$, and the variables used are presented in Table 2.

The physical carrying capacity in each trail is 150 people, without taking into account comfort or functionality, only the space required.

The Real Carrying Capacity (RCC) determines the conditions of comfort and the distances to provide conditions of comfort for tourists. Table 3 presents the variables used for its calculation per trail.

b) The Real Carrying Capacity (RCC) is defined by subjecting the PCC to a series of correction factors that are applicable to each site. The correction factors are obtained considering physical, environmental, social and management factors. In this case, the following correction factors were taken:

i) Social Factor (FCsoc), which is calcualted when defining aspects of comfort in the territory, time of the tour, spaces required for observation, and avoiding tourist overcrowding; 
condiciones de confort a los turistas. En el Cuadro 3 se presentan las variables utilizadas para su cálculo por sendero.

b) La capacidad de carga real (CCR), se determina sometiendo la CCF a una serie de factores de corrección que son aplicables a cada sitio. Los factores de corrección se obtienen considerando factores físicos, ambientales, sociales y de manejo. En este caso se tomaron: los siguientes factores de reducción:

i) Factor social (FCsoc), el cual se calcula al determinar aspectos de comodidad en el territorio, tiempo de recorrido, espacios requeridos para la observación y evitar el hacinamiento de turistas;

ii) Factor de erodabilidad (FCero), sobre el número de visitas y la susceptibilidad del terreno tiene para la erosión tomando en cuenta la pendiente del terreno para determinar el grado de susceptibilidad a la erosión. En el Cuadro 4, se presentan los parámetros para determinar el factor de ponderación de erodabilidad.

iii) Factor de accesibilidad (FCacc), se mide el grado de dificultad que tiene el turista para moverse libremente debido a la pendiente del terreno. En el Cuadro 5 se presentan los parámetros para el cálculo del Factor de accesibilidad.

iv) Factor de cierres temporales (FCct), el cual limita el tiempo de actividades turísticas en el sitio. Es este caso el factor lo determina la temporalidad del apareamiento de la luciérnaga que abarca tan sólo dos meses y medio.

La estimación se calcula de la siguiente forma:

$$
C C R=\operatorname{CCF}^{*}\left(F C \operatorname{soc}^{*} F \operatorname{Cero}^{*} F \operatorname{Cacc}^{*} F C c t\right)
$$

Capacidad de carga efectiva (CCE) representa el límite máximo que puede recibir un sendero dada la capacidad para ordenarla y manejarla. Para el cálculo se tomaron factores de capacidad de manejo $(\mathrm{CM})$, esta se define como la suma de condiciones que la administración del área necesita para poder cumplir a cabalidad con sus funciones y objetivos (Amador, Cayot, Cifuentes, Cruz y Cruz, 1996).

Se toma en cuenta el límite aceptable de uso al considerar la capacidad de manejo, servicios y administración del sitio, número de guías, servicios al turista en el poblado, equipos de primeros auxilios
Cuadro 3. Variables para el cálculo de la capacidad de carga real.

Table 3. Variables for the calculation of the real carrying capacity.

\begin{tabular}{lc}
\hline \multicolumn{2}{c}{ Calculo de la capacidad de carga real } \\
\hline Distancia requerida & $72 \mathrm{~m}$ \\
Grupos en simultaneo por sendero & 4.17 \\
Total de personas por sendero & 45.83 \\
Magnitud Limitante & $208.33 \mathrm{~m}$ \\
\hline
\end{tabular}

ii) Erodability Factor (FCero), regarding the number of visits and the susceptibility of the terrain to erosion, taking into account the slope of the terrain to determine the degree of susceptibility to erosion. Table 4 presents the parameters to determine the weighing factor of erodability.

iii) Accessibility Factor (FCacc), which measures the degree of difficulty faced by the tourist to move freely due to the terrain's slope. Table 5 presents the parameters for the calculation of the accessibility factor.

iv) Temporary Closure Factor (FCct), which limits the time of tourist activities in the site. In this case the factor is determined by the seasonality of firefly mating that covers only two months and a half.

The estimation is calcuated in the following way:

$$
C C R=C C F^{*}\left(F C \operatorname{soc}^{*} F C e r o^{*} F C a c c^{*} F C c t\right)
$$

The Effective Carrying Capacity (ECC) represents the maximum limit that a trail can receive given the capacity to order it and manage it. To calculate this, management capacity (MC) factors were taken, which are defined as the sum of conditions that the administration of the area needs in order to be able to thoroughly fulfill their

Cuadro 4. Parámetros para el cálculo del Factor de erodabilidad (FCero).

Table 4. Parameters for the calculation of the Erodability Factor (FCero).

\begin{tabular}{clc}
\hline \multicolumn{3}{c}{ Factor de erodabilidad (FCero) } \\
\hline Pendiente & Nivel & Ponderación \\
\hline Menor que $10 \%$ & Bajo & 0 \\
$10 \%-20 \%$ & Medio & 1 \\
Mayor que 20\% & Alto & 1.5 \\
\hline
\end{tabular}


y comunicación requeridos por las normas oficiales y número de módulos de información. Los aspectos fueron evaluados siguiendo la escala de 0 a 4 establecida en trabajos similares de Cifuentes (1992).

Para calcular la capacidad de manejo, se tomaron los requisitos mínimos para los operadores turísticos de acuerdo al reglamento aceptado, así como la infraestructura hotelera y de servicios de alimentación del municipio. En el Cuadro 6, se presentan la infraestructura y servicios tomados en cuenta para el cálculo del factor de ponderación de la capacidad de manejo.

Una vez estimada y categorizada la CM, es posible estimar la CCE, mediante la siguiente fórmula: $C C E=C C R \times C M$.

Cortés (2009) realizó una validación de la aplicación del método en varios contextos de áreas naturales, concluye que la capacidad de carga presenta un amplio espectro de utilizaciones que permiten aportar materias que pueden ayudar al diseño de instrumentos de planificación territorial.

\section{RESULTADOS Y DISCUSIÓN}

En la aplicación del modelo de turismo sustentable se utiliza frecuentemente el concepto de capacidad de carga, que implica que los lugares turísticos poseen ciertos límites en el volumen y la intensidad que puede soportar una zona geográfica determinada, sin que provoque daños irreparables (López y López, 2008).

El ecoturismo puede ser el motor del desarrollo rural, siempre y cuando la comunidad en la que se or-

Cuadro 6. Factor correspondiente a la infraestructura y servicios de la capacidad de manejo.

Table 6. Factor corresponding to the infrastructure and services of the management capacity.

\begin{tabular}{lc}
\hline \multicolumn{1}{c}{$\begin{array}{c}\text { Factores resultado del cálculo } \\
\text { de la capacidad de manejo }\end{array}$} & Factor \\
\hline Oficina de informes & 0.471 \\
Guías & 0.358 \\
Senderos habilitados & 1.000 \\
Baños & 0.667 \\
Señalización & 0.500 \\
Radios & 0.667 \\
Botiquín de primeros auxilios & 0.500 \\
Cuartos de hotel & 0.714 \\
Restaurantes & 0.800 \\
Personas entrenadas para primeros auxilios & 0.570 \\
\hline
\end{tabular}

Cuadro 5. Parámetros para el cálculo del Factor de accesibilidad (Fcacc).

Table 5. Parameters for the calculation of the accessibility factor (Fcacc)

\begin{tabular}{lcc}
\hline \multicolumn{3}{c}{ Factor de accesibilidad (Fcacc) } \\
\hline $\begin{array}{l}\text { Grado de } \\
\text { dificultad }\end{array}$ & Pendiente & $\begin{array}{c}\text { Valores de } \\
\text { ponderación }\end{array}$ \\
\hline Ninguno & $<10 \%$ & No significativo \\
Medio & $10 \%-20 \%$ & 1 \\
Alta & $>20 \%$ & 1.5 \\
\hline
\end{tabular}

functions and objectives (Amador, Cayot, Cifuentes, Cruz and Cruz, 1996).

The acceptable limit of use is taken into account when considering the capacity of management, services and administration of the site, number of guides, services for tourists in the town, first aid teams, and communication required by the official norms and the number of information modules. The aspects were evaluated following the scale of 0 to 4 established in similar studies by Cifuentes (1992).

To calculate the capacity of management, the minimal requirements for tourist operators according to the accepted regulations were considered, as well as the hotel and food services infrastructure in the municipality. Table 6 presents the infrastructure and services taken into account for the calculation of the weighing factor of the management capacity.

Once the $\mathrm{MC}$ was estimated and categorized, it is possible to estimate the ECC, through the following formula: $C C E=C C R \times C M$.

Cortés (2009) attested tothe application of the method in various natural area contexts, concluding that the carrying capacity presents a broad spectrum of uses that allows contributing materials that can help in the design of instruments for territorial planning.

\section{RESULTS AND DISCUSSION}

In the application of the sustainable tourism model the concept of carrying capacity is frequently used, which implies that tourist sites have certain limits in the volumen and the intensity that a specific geographical area can bear, without causing irreparable damage (López and López, 2008).

Ecotourism can be the motor of rural development, as long as the community where it is organized is capable of taking advantage of the natural resources and become organized to offer a service that caters 
ganice sea capaz de aprovechar los recursos naturales y organizarse para ofrecer un servicio acorde con las necesidades del turismo. De acuerdo con la Organización de las Naciones Unidas para la Alimentación y la Agricultura (FAO, 2005), el ecoturismo puede ofrecer notables beneficios a nivel local y nacional.

En Nanacamilpa para el manejo turístico existen reglas de comportamiento del turista establecidas en 2013, estas reglas son publicadas en espacios públicos y cartelones en el poblado y se espera que el turista las respete. La promoción turística permitió el incremento en el número de visitantes a la zona, de acuerdo a los datos proporcionados por el Municipio, la afluencia de turistas pasó de 71636 en 2015 a 90000 en 2016. Este flujo turístico es atendido en los meses de avistamiento que comprenden del 16 de julio al 13 de agosto, cabe mencionar que los días de inicio pueden variar de acuerdo a los periodos establecidos por el municipio.

En 2016, se registraron 17 predios para ofrecer el servicio, se capacitaron y certificaron 30 guías locales más los que ya estaban registrados se alcanzó un total de 43 guías certificados.

El recorrido de avistamiento consiste en agrupar a los turistas que arriban a los sitios de observación a partir de las $8 \mathrm{pm}$, se les asigna un guía y a las 8:30 inicia el recorrido a pie a través de los senderos. El guía va a la cabeza del grupo mientras van avanzando por el sendero, la caminata es continua hasta salir del sendero.

El turismo abarca un contexto donde la gobernanza contempla la intersección de lo público, lo privado y las comunidades (Fernández de Santana, Fontes y Barroso, 2015). En el caso de Nanacamilpa cada grupo establece sus tarifas y el tipo de servicio que ofrece, esto implica que no existe una regulación referente al número de turistas que tienen acceso al área ni controles del manejo del ecosistema. Este tipo de operación, si no se toman medidas de protección puede afectar el ecosistema forestal impactando no solamente al dueño del predio bajo manejo sino a todo el sistema de reproducción de la liciérnaga. El paso de los turistas por los senderos, implica una compactación del suelo y daño en la vegetación de las orillas del sendero, las luciernadas depositan los huevos en la tierra y el proceso de apareamiento se realiza en los estratos bajos de vegetación, por lo que elimpacto es muy significativo.

Aunque las experiencias de turismo comunitario registradas en escala nacional suelen ser heterogéneas, for the needs of tourists. According to the Food and Agriculture Organization of the United Nations (FAO, 2005), ecotourism can offer notable benefits at the local and the national level.

In Nanacamilpa, for tourism management there are rules of behavior for the tourist established in 2013; these rules are displayed in public spaces in and around the village and it is expected that tourists respect them. Tourism promotion allowed the increase in the number of visitors to the area; according to data provided by the municipality, the tourist influx went from 71636 in 2015 to 90000 in 2016. The tourist arrives during the sightseeing months from July 16 to August 13; it should be mentioned that the dates could vary according to the periods established by the municipality.

In 2016, 17 plots offereing service were registered, 30 local guides were trained and certified plus those already registered, bringing the number of certified guides to 43 .

The sighting tour consists in grouping tourists who arrive at the observation sites starting at $8 \mathrm{pm}$; a guide is assigned to them, and at 8:30 the $r$ walking tour begins through the trails. The guide leads the group through the trail, and the walk is continuous until leaving the trail.

Tourism encloses a context where governance involves the intersection of the public, the private, and the communities (Fernández de Santana, Fontes and Barroso, 2015). In the case of Nanacamilpa each group establishes their fees and the type of service on that it offers, this implies that there is no regulation of the number of tourists accessing the area and no controls of the management of the ecosystem. This type of operation, if protection measures are not taken, can affect the forest ecosystem impacting not only the owner of the plot under management but rather the whole firefly reproduction system. The passage of tourist on the trails involves soil compaction and damage to the vegetation on the edges of the trails, the fireflies lay their eggs in the soil and the mating process takes place in the lower strata of vegetation, so the impact is very significant.

Although the experiences of community tourism recorded at the national scale tend to be heterogeneous, their degree of consolidation has depended in part on the ability to structure and strengthen their community institutions and governance systems (Palomino et al., 2015). 
su grado de consolidación ha dependido en parte de la capacidad de estructurar y fortalecer sus instituciones comunitarias y sistemas de gobernanza (Palomino et al., 2015).

En Nanacamilpa, las iniciativas no están ligadas a una estructura institucional, simplemente se realizan reuniones en donde se dan a conocer las reglas establecidas por el gobierno municipal y estatal, y las sanciones establecidas en la Ley General de Turismo, esta situación pone en riesgo el manejo integral del turismo. Es necesario que se integre un comité local que vigile que los acuerdos y compromisos adquiridos en las reuniones previas de organización se cumplan, así como se implementen sanciones para los infractores.

Cuando existe una intervención sobre un sistema económico, social o ambiental, generalmente aparece una serie de cambios en las propiedades estructurales a nivel cualitativo y cuantitativo, estas transformaciones en el estado de los sistemas a su vez crean nuevas condiciones que pueden ser tanto aceptables como no deseadas en términos del cumplimiento de un objetivo (SECTUR, 2007).

La afluencia de turistas al municipio le ha dado una nueva percepción a la población y el comercio del valor del bosque como un medio alternativo de actividad económica. El sistema ambiental de Nanacamilpa fue el detonante del turismo local por lo que su uso y conservación son la base para el desarrollo comunitario.

\section{Análisis de la capacidad de carga en los senderos}

El análisis de capacidad de carga se basó en los datos de visitantes que se atendieron en 2016, el municipio registró 90000 visitantes, y se registraron 17 predios funcionando, con un total de 43 guías certificados, para la capacidad de manejo se tomaron las regulaciones establecidas por la secretaría de turismo para la operación de centros ecoturísticos. Cabe mencionar que el número de visitantes por predio no se distribuye homogéneamente, se establece un centro de atención al turista en donde los predios ofertan sus servicios y cada turista es libre de contratar con cualquiera de los ofertantes, por lo que en algunos casos puede estar saturado el servicio. Las iniciativas también contratan promotores locales que se colocan en los caminos de acceso principales ofreciendo los servicios, por lo que algunos turistas no pasan por el centro de atención.
In Nanacamilpa, the initiatives are not linked to an institutional structure, meetings are simply held where the rules established by the municipal and state government, as well as the sanctions established in the General Tourism Law are made known, situation which places at risk the integral management of tourism. It is necessary to create a local committee to ensure that agreements and commitments acquired in the prior organization meetings are fulfilled, as well as to implement sanctions for offenders.

When there is an intervention on an economic, social or environmental system, there is usually a series of changes in the structural properties at the qualitative and quantitative level; these transformations in the state of the systems in turn create new conditions that may be either acceptable or undesirable in terms of the meeting an objective (SECTUR, 2007).

The influx of tourists to the municipality has given the population and commerce a new perception of the value of the forest as an alternative means of economic activity. The environmental system of Nanacamilpa was the detonator of the local tourism so its use and conservation are the basis for community development.

\section{Analysis of the Carrying Capacity in the Trails}

The analysis of the carrying capacity was based on the data of visitors that were received in 2016. The municipality registered 90000 visitors, and 17 functioning plots, with a total of 43 certified guides; for the management capacity, the regulations established by the tourism authorities for the operation of ecotourism centers were taken into account. It is worth mentioning that the number of visitors per plot is not distributed homogeneously; a tourist attention center is established where the plots offer their services and each tourist is free to contract with any of the providers, in some cases the service may be saturated. The initiatitives also hired local promoters who are placed on the main access roads offering the services, so that some tourists do not pass through the tourist center.

An average of 1200 visitors per day were attended, and it should be noted that the visits are not evenly spread over the days of the week, but that there is an overload mainly on Fridays and Saturdays. 
Se atendió un promedio 1200 visitantes por día, cabe señalar que las visitas no se dan homogéneamente en los días de la semana, sino que hay una sobrecarga principalmente los viernes y sábados.

Se contabilizaron 19 senderos en total, algunos predios cuentan con 2 senderos de avistamiento, el promedio de longitud de los senderos es de $300 \mathrm{~m}$ y el flujo de visitantes es en un solo sentido. Cada visitante necesita $2 \mathrm{~m}$ para caminar libremente en el sendero. Cabe señalar que Cifuentes (1999) propone $1 \mathrm{~m}$ por persona, sin embargo, Puente et al. (2011) que propone $4 \mathrm{~m}$ por persona en senderos de mariposa monarca, por lo que se hizo un promedio entre las dos propuestas

La distancia entre grupos es de $50 \mathrm{~m}$ para no tener interferencias, los grupos se calcularon de 10 personas más un guía de acuerdo a la Norma Oficial mexicana NOM-06-TUR-2009.

El tiempo de recorrido es de dos horas, pues es el máximo que dura el espectáculo por lo que los senderos se abren por el mismo lapso de tiempo, lo que significa que se puede hacer una visita por día por cada persona, la actividad se realiza solamente en dos meses y medio del ańo.

\section{Factores de corrección}

El factor social (FCsoc) resulta del factor limitante que se refiere al espacio que no puede ser utilizado ya que se deben mantener $50 \mathrm{~m}$ entre cada grupo y se divide entre la longitud del sendero lo que nos da 69.44 como factor de corrección.

Los senderos se encuentran en cañadas con muy poca pendiente, se consideraron pendientes moderadas de entre 10 y $20 \%$ al inicio y la salida de la cańada por lo que para el factor de erodabilidad (FCero) se tomaron $20 \mathrm{~m}$ con un grado de pendiente medio lo que nos da $6.67 \%$ de factor de corrección. Es el mismo caso para el factor de accesibilidad (FCacc), pues las áreas de pendiente son las mismas.

Para calcular la temporada de avistamiento se toman dos meses y medio que corresponde a la temporada establecida del 6 de junio al 13 de agosto y son las fechas de apareamiento de la luciérnaga, el ciclo biológico de la especie es anual, por lo que después del apareamiento el resto del ańo se completa el ciclo reproductivo.

Aplicando los factores de reducción, la capacidad de carga real (CCR) es de 32 personas por sendero, si
In total, 19 trails were counted, some plots have 2 sighting trails, the average length of the trails is $300 \mathrm{~m}$ and the flow of visitors is one direction only. Each visitor needs $2 \mathrm{~m}$ to walk freely on the trail. It should be noted that Cifuentes (1999) proposes $1 \mathrm{~m}$ per person; however, Puente et al. (2011) suggest $4 \mathrm{~m}$ per person on monarch butterfly trails, so an average was made between the two proposals.

The distance between groups is $50 \mathrm{~m}$ in order to avoid interferences, the groups were calculated with 10 people plus a guide according to the Mexican Official Norm NOM-06-TUR-2009.

The tour lasts two hours, which is the maximum time the spectacle lasts, so the trails are opened for the same amount of time, which means that one person can make one visit per day; the activity takes place only in two and a half months of the year.

\section{Correction factors}

The social factor (FCsoc) results from the limiting factor that refers to the space that cannot be used, as $50 \mathrm{~m}$ must be maintained between each group and is divided by the length of the trail wich gives 69.44 as the correction factor..

The trails that are found in the small gullies with very little slope at the start and exit of the gullies the incline is between 10 and $20 \%$ which is considered a moderate slope, so for the erodibility factor , so (FCero), it was considered a $20 \mathrm{~m}$ hight with a medium slope which gives us $6.67 \%$ correction factor. It is the same in the case of the accessibility factor (FCacc), as the slope areas are the same.

To calculate the sighting season, the two months and a half that correspond to the season established from June 6 to August 13 are taken, which are the firefly mating dates. The biological cycle of the species is annual, so that after mating the rest of the year the reproductive cycle is completed.

Applying the reduction factors, the real carrying capacity (RCC) is 32 people per trail, if taking into account that an average of 1200 people are received per day, each initiative would have to cater for 71 people if it were a constant influx seven days a week and should have at least two trails to adequately catero for the tourist flow.

Taking into account the tourist services of the municipality, a management capacity of 0.625 was obtained, which when applied to the real carrying 
se toma en cuenta que se recibe en promedio de 1200 personas al día, cada iniciativa tendría que atender 71 personas si fuera una afluencia constante en los siete días de la semana y deberían tener por lo menos dos senderos para la atención adecuada del flujo turístico.

Tomando en cuenta los servicios turísticos del municipio se obtuvo una capacidad de manejo de 0.625 , que al aplicarlo a la capacidad de carga real nos da una capacidad de carga efectiva (CCE) de 25 personas por sendero, cantidad que es rebasada por la afluencia de turistas especialmente los fines de semana. Los resultados se presentan en el Cuadro 7.

Si se toma la capacidad de carga efectiva por sendero se determina que el número máximo de visitantes por día es de 466 personas en todos los senderos. La capacidad de carga es sobrepasada por 734 personas diarias en el supuesto de que se diera un número de visitantes constante durante la semana, los fines de semana se recibe casi $80 \%$ de las visitas semanales. De acuerdo a Ibañez (2016) la CCT no representa un número mágico que garantice por sí sola la preservación y protección de un área, ni mucho menos resuelve los impactos negativos que la actividad turística pueda llegar a generar dentro de los senderos analizados; pero, aun con ello, sí representa un instrumento único de apoyo para la gestión y conservación de cualquier zona, sea o no un área natural protegida.

La sobrecarga de turistas en los senderos provoca afectaciones directas al ecosistema como compactación de suelos, muerte de hembras que están a nivel del suelo, generación de residuos sólidos, daño a la cubierta vegetal entre otros. Estas afectaciones son permanentes para el ciclo de reproducción de la luciérnaga pues de acuerdo a Méndez-Montiel J. T. y Campos-Bolaños (2016) el ciclo de reproducción es anual y el periodo de apareamiento representa la etapa más critica del ciclo.

Derivado del estudio de la capacidad de carga se proponen recomendaciones para el manejo del turismo que cumplan las funciones de protección a la luciérnaga y brindar un buen servicio, estas están basadas en la observación del manejo turístico y los recorridos por senderos en época de avistamiento. De acuerdo a López y López, (2008) con los resultados de estudios de capacidad de carga, los gestores turísticos estarán en mejores condiciones para identificar las cuestiones emergentes, lo que permite su prevención o mitigación; para identificar los impactos, lo que permite actuar antes de que ocasionen problemas; capacity gives us an effective carrying capacity (ECC) of 25 people per trail, an amount that is exceeded by the influx of tourist, especially on weekends. The results are presented in Table 7 .

Taking the effective carrying capacity per trail is taken, it is determined that the maximum number of visitors per day is 466 people on all trails. The carrying capacity is exceeded by 734 people per day assuming a constant number of visitors during the week, with weekends receiving almost $80 \%$ of the weekly visits. According to Ibañez (2016) the TCC does not represent a magic number that alone guarantees the preservation and protection of an area, and much less resolves the negative impacts that the tourist activity can generate within the trails analyzed; but, even so, it does represent a unique instrument of support for the management and conservation of any area, whether or not it is a natural protected area.

The overload of tourist on the trails causes direct impacts on the ecosystem such as soil compaction, death of females at ground level, generation of solid waste, damage to the vegetation, among others. These affectations are permanent for the reproduction cycle of fireflies since according to Méndez-Montiel and Campos-Bolaños (2016), the reproduction cycle is annual and the mating period represents the most critical stage of the cycle.

Based on the study of the carrying capacity, recommendations are proposed for the management of tourism to fulfil the functions of protecting the fireflies and providing a good service, these are based on the observation of tourist management and walks along the trails trails during the sighting season. According to López and López (2008), with the results of carrying capacity studies, tourist managers

Cuadro 7. Resultados del cálculo de la Capacidad de Carga. Table 7. Results from calculating the Carrying Capacity.

\begin{tabular}{lc}
\hline \multicolumn{1}{c}{$\begin{array}{c}\text { Resultados del cálculo de la } \\
\text { Capacidad de Carga }\end{array}$} & Factor \\
\hline Capacidad de carga física & 150 \\
Factores de corrección & 1.00 \\
Factor Social & 0.99 \\
Factor de erodabilidad & 0.99 \\
Factor de accesibilidad & 0.99 \\
Factor de cierres temporales & 32 \\
Capacidad de carga real & 0.62 \\
Capacidad de manejo & 25 \\
Capacidad de carga efectiva por sendero & \\
\hline
\end{tabular}


para apoyar el desarrollo del turismo sustentable, determinando límites y oportunidades; y para fomentar la responsabilidad de los gestores, promoviendo la adopción de decisiones responsables basadas en el conocimiento.

La protección del hábitat es uno de los aspectos más importantes para el desarrollo sustentable del destino, por lo que se deben tener lineamientos de uso basados en la capacidad de carga de los senderos para la protección de la luciérnaga, estos deben ser aceptados por todos los prestadores de servicios turísticos y reglamentados para su implementación.

Cualquier aproximación para el desarrollo debe partir de la identificación de las condiciones ambientales, sociales y económicas deseadas por una comunidad y sentar las estrategias de desarrollo que permitan gestionar la capacidad de carga turística en esa dirección (Echamendi, 2001). Para lograr las condiciones de calidad de servicios y protección del medio ambiente de deben estandarizar las reglas de operación para el manejo del turismo en la zona de bosque, tales como: tamaño de los grupos, turistas manejados por cada guía, instalaciones mínimas para la prestación de servicios. Estas reglas deberán ser consensadas y aceptadas por todos los prestadores de servicios.

Instalar en los senderos caminos en plataformas en alto para evitar que se pisen las luciérnagas en el suelo, y cada $50 \mathrm{~m}$ poner estaciones de observación en donde el turista pueda sentarse a disfrutar el fenómeno sin necesidad de mantenerse en movimiento por el sendero. Esta estrategia evita accidentes y protege a la luciérnaga.

\section{CONCLUSIONES}

El ecoturismo en Nanacamilpa representa una actividad importante a nivel municipal, el periodo de junio a agosto representa un periodo muy corto pues son las fechas de avistamiento se recibe turismo que hace una derrama económica importante en los negocios locales, sin embargo están impactando negativamente el hábitat de la luciérnaga por la sobrecarga de visitantes en los senderos. Este periodo es particularmente vulnerable porque se da el apareamiento de la luciérnaga, lo que representa la reproducción de la especie. El ciclo de reproducción es anual, por lo que la protección permanente del ecosistema es la base para la continuidad del fenómeno natural. will be in better position to identify the emerging issues enabling their prevention or mitigation; to identify the impacts, enabling them to act before they cause problems; to support sustainable tourism development, defining limits and opportunities; and to foster the responsibility of managers, promoting responsible decision-making based on knowledge.

Habitat protection is one of the most important aspects for the sustainable development of the destination, so guidelines for the use based on the carrying capacity of the trails for protection of the firefly, which must be accepted by all the tourist service providers and regulated for their implementation.

Any approach to development must start from the identification of the environmental, social and economic conditions desired by a community, and set out development strategies to managing the tourist carrying capacity in that direction (Echamendi, 2001). In order to achieve the conditions of quality of service and environmental protection, the operation rules for tourist management in the forest area should be standardized, such as: size of groups, tourists handled per guide, minimum facilities for the provision of service. These rules should be agreed and accepted by all service providers.

Installing paths on high platforms on the trails to prevent fireflies being crushed on the ground, and placing observation stations every $50 \mathrm{~m}$ where the tourist can sit to enjoy the phenomenon without having to keep moving along the trail. This strategy prevents accidents and protects the firefly.

\section{CONCLUSIONS}

Ecotourism in Nanacamilpa represents an important activity at the municipal level, the period from June to August represents a very short period as these are the sighting dates when tourism is received which brings significant economic revenue to local businesses; however, it is negatively impacting the habitat of the firefly due to the overload of visitors on the trails. This period is particularly vulnerable because of the firefly's mating season, which represents the reproduction of the species. The reproduction cycle is annual, so the permanent protection of the ecosystem is the basis for the continuity of the natural phenomenon.

The study of the carrying capacity allows the maximum number of visitors to be established so 
El estudio de capacidad de carga permite establecer el número máximo de visitantes para que no se alteren las condiciones ambientales. En la temporada 2016 se recibió un promedio de 1200 visitantes al día y el estudio arrojó un máximo permisible de 466 visitantes por día en todos los senderos, sobrepasando en $258 \%$ la capacidad de carga de los senderos y se espera que la tendencia de número de visitantes se incremente por la promoción turística y el auge de los turistas que buscan destinos que ofrecen sitios naturales. En la aplicación del modelo de turismo sostenible se utiliza frecuentemente el concepto de capacidad de carga, que implica que los lugares turísticos poseen ciertos límites en el volumen y la intensidad que puede soportar una zona geográfica determinada, sin que provoque daños irreparables. (Lopez y López 2008)

Si se controla el flujo turístico, la disminución del número de visitantes acarrea una baja en los ingresos de los prestadores de servicios turísticos y en la derrama económica del municipio, sin embargo, estas medidas disminuyen los impactos ambientales del área de bosque pues uno de los principales problemas es la compactación del suelo y la afectación a la vegetación. A nivel social con la baja del flujo turístico se dismunuirá la cantidad de turistas en el poblado, por lo que se pueden ofrecer mejores servicios de apoyo al turismo como lugares para alimentación, sanitarios y centros de descanso en el poblado. Actualmente, princialpmente en los fines de semana los servicios locales son insuficientes para atender la demanda.

De acuerdo a las tendencias de visitantes se puede concluir que el flujo turístico va en aumento anualmente, por lo que es necesario que se tomen las medidas de protección ambiental en los predios mediante el cumplimiento de la capacidad de carga por sendero. Así mismo es necesario que se regule el número de predios que ofrecen el servicio pues se tiene que dejar áreas de amortiguamiento que no reciban turistas que cumplan la función de protección a la reproducción de la especie.

\section{LITERATURA CITADA}

Álvarez-Icaza L. P. 2005. Manejo de recursos de uso común en regiones costeras. Sección v. Herramientas e instrumentos para la gestión costera. En Manejo costero integral: el enfoque municipal. Patricia Moreno-Casasola, Elisa Peresbarbosa Rojas, Ana Cecilia Travieso Bello (Editores). Instituto de Ecología, A.C. 1266 pp

Amador E., Cayot L., Cifuentes M., Cruz E., y Cruz F. 1996. Determinación de la capacidad de carga turística en los sitios de that environmental conditions are not altered. In the 2016 season an average of 1200 visitors per day were received, and the study showed a maximum allowable number of 466 visitors per day on all trails, exceeding by $258 \%$ the carrying capacity of the trails, and it is expected that the trend inf visitor numbers will increases due to tourism promotion and the boom in tourists who seek destinations that offer natural sites. In the application of the sustainable tourism model the concept of carrying capacity is frequently used, which implies that tourist places have certain limits on the volume and the intensity that a given geographical area can withstand, without it causing irreparable damage (Lopez and López, 2008).

If the tourist flow is controlled, the decrease in the number of visitors leads to a decrease in the income of the tourist service providers also affecting other trades and servces on offer throughout the municipal area; however, these measures decrease the environmental impacts of the forest area since one of the main problems is soil compacting and affectation on the vegetation. On a social level, with the decrease of tourist flow the number of tourists in the village will decrease, so that better support services for tourist could be offered such as places to eat, restrooms, and rest centers in the village. At present, especially on weekends local services are insufficient to meet the demand.

According to visitor trends, it can be concluded that tourist flow is increasing annually, so it is necessary to take environmental protection measures on the plots by compliying with the carrying capacity per trail. It is also necessary to regulate the number of plots that offer the service, as buffer areas that do not receive tourists must be left to fulfil the function of protecting the reproduction of the species.

\section{- End of the English version-

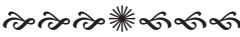

visita del parque nacional Galápagos. Servicio Parque Nacional Galápagos. Instituto Ecuatoriano Forestal y de Áreas Naturales y Vida Silvestre. Puerto Ayora, Islas Galápagos. Obtenido de http://81.47.175.201/stodomingo/attachments/article/205/ CCT_Galapagos.pdf

Antinori, C., and. Rausser-Gordon C. 2010. The Mexican Common Property Forestry Sector. CUDARE Working Papers. Paper $1105.83 \mathrm{p}$.

Arnaiz, B. S. M., y César, D. A. C. 2004. Sustentabilidad, Pobreza y Turismo. Estudios y Perspectivas en Turismo. 13. 160 - 173. 
Obtenido de http://www.estudiosenturismo.com.ar/search/ PDF/v13n1y2a10.pdf

Butler, R. W. 1980. The concept of a tourism area cycle of evolution: Implications for management of resources, Canadian Geographer 24(1). 5-12. doi: 10.1111/j.1541-0064.1980.tb00970.x

Cifuentes, M., 1992 Determinación de capacidad de carga turística en áreas protegidas. Turrialba, Costa Rica. CATIE. Obtenido de https://www.ucm.es/data/cont/media/www/pag-51898/1992_ METODOLOG\%C3\%8DA\%20CIFUENTES.pdf

Cifuentes, M. 1999. Capacidad de Carga Turística en las Áreas de uso público del Monumento Nacional Guayabo, Costa Rica. WWF-Centro Agronómico de Investigación y Enseñanza (CATIE) Obtenido de www.wwfca.org/wwfpdfs/Guayabo.PDF

CONAFOR (Comisión Nacional Forestal). 2013. El bosque de oyamel de Nanacamilpa, hábitat de las luciérnagas. Comisión Nacional Forestal. Gerencia Estatal Tlaxcala. Consultado 09-05-2016 en http://www.conafor.gob.mx:8080/documentos/docs/7/4925El\%20bosque\%20de\%20oyamel\%20 de $\% 20$ Nanacamilpa, $\% 20$ h\%C3\%A1bitat $\% 20$ de $\% 20$ las $\% 20$ luci\%C3\%A9rnagas.pdf

Cortés, C. S. 2009. La capacidad de carga como herramienta para la ordenación sostenible del territorio. Cuaderno de Investigación Urbanística. 65.35-56

Echamendi Lorente, P. 2001. La capacidad de carga turística. Aspectos conceptuales y normas de aplicación. Anales de Geografla de la Universidad complutense. 21:pp. 11-30

Fernández de Santana, V., Fontes F. J. R., y Barroso R. S. 2015. Gestión local de recursos de uso común en turismo: La perspectiva de Elinor Ostrom. Estudios y perspectivas en turismo, 24(1), 56 -75. Obtenido de http://www.scielo.org.ar/scielo. php?script=sci_arttext $\&$ pid $=\$ 1851-17322015000100004 \& \ln$ $\mathrm{g}=\mathrm{es} \& \mathrm{t} \operatorname{lng}=\mathrm{es}$.

Guerrero, R. R. 2010. Ecoturismo Mexicano: la promesa, la realidad y el futuro. Un análisis situacional mediante estudios de caso. El Periplo Sustentable. 18. 37-67. doi: 10.21854/eps.v0i18.913

Ibañez, P. R. 2016. Capacidad de carga turística como base para el manejo sustentable de actividades ecoturísticas en Unidades de Manejo Ambiental (UMA) de Baja California Sur (BCS). El Periplo Sustentable Número: 30. Pp 37- 76. doi. 10.21854/ eps.v0i30.3534

INAFED. 2016. Enciclopedia de los municipios y delegaciones de México. Nanacamilpa de Mariano Arista. Consultado el 5 de septiembre de 1016. http://www.inafed.gob.mx/work/enciclopedia/EMM29tlaxcala/index.html

INEGI. 2010. Censo de población y vivienda. Instituto Nacional de Estadística y Geografía, México.

López, B. J. M., y López B. L. M. 2008. La capacidad de carga turística: Revisión crítica de un instrumento de medida de sostenibilidad. El Periplo Sustentable. 15. 123 - 150. doi. 10.21854/ eps.v0i15.938

Mathieson, A., y Wall G. 1982. Tourism: economic, physical and social impacts. Longman, Harlow, London.

Mc-Coy, C. C.E., y Sosa F. A. P. 2016. Causas y efectos de un destino no sustentable: Caso playas públicas de Cancún, Quintana Roo. El Periplo Sustentanle. 31. doi 10.21854/eps.v0i31.2468

Méndez-Montiel, J. T., y Campos-Bolaños R. 2016. Entrevista personal. Universidad Autónoma Chapingo
OMT (Organización Mundial del Turismo). 2015. Las Naciones Unidas proclaman 2017 Año Internacional del Turismo Sostenible para el Desarrollo. Press Release. Programa de Comunicación y Publicaciones de la OMT. http://media.unwto.org/ es/press-release/2015-12-10/las-naciones-unidas-proclaman2017-ano-internacional-del-turismo-sostenible

OMT (Organización Mundial del Turismo). 2017. Definición. Autor. Obtenido de http://sdt.unwto.org/es/content/definicion

ONU (Organización de las Naciones Unidas para la Alimentación y la Agricultura (FAO)). 2005. Ordenación, conservación y desarrollo sostenible de los bosques Situación de los bosques en el mundo. Roma, Italia. Autor. Obtenido de ftp://ftp.fao.org/ docrep/fao/007/y5574s/y5574s05.pdf

ONU (Organización de las Naciones Unidas para la Alimentación y la Agricultura (FAO)). 2010. Evaluación de los recursos forestales mundiales 2010. Roma, Italia. Autor. Obtenido de http:// www.fao.org/docrep/013/i1757s/i1757s.pdf

ONU (Organización de las Naciones Unidas). 2002. Plan de Aplicación de las Decisiones de la Cumbre Mundial sobre el Desarrollo

Palomino, V. B., Gasca Z. J., y López P. G. 2015. El turismo comunitario en la Sierra Norte de Oaxaca: perspectiva desde las instituciones y la gobernanza en territorios indígenas. El Periplo Sustentable. 30. 6 - 37. doi: 10.21854/eps.v0i30.2465

Puente, S. E. D., Pérez R. C. A., y Solís B. C. I. 2011. Capacidad de Carga en Senderos Turísticos del Centro de Cultura para la Conservación Piedra Herrada, México. Quivera, 13 (2). 93 - 114. Obtenido de http://www.redalyc.org/articulo. oa?id=40119956005

Saarinen, J. (2006) "Tradiciones de sostenibilidad en los estudios turísticos”. Annals of Tourism Research en español. 8(2), 243264.

SECTUR. 2016. Ocupación en hoteles y moteles por centro turístico, corte mensual. DataTur. http://www.datatur.sectur.gob.mx/ RAT/RAT-2016-12(ES).pdf

SECTUR (Secretaría de Turismo). 2007. Elementos para Evaluar el Impacto Económico, Social y Ambiental del Turismo de Naturaleza en México. Autor. Obtenido de http://ictur.sectur.gob. $\mathrm{mx} / \mathrm{pdf} /$ estudioseinvestigacion/sustentabilidad/METODOLOGIA_SUSTENTABILIDAD_1d3.pdf

SEGOB-CEDEMUN. 2001. Enciclopedia de los Municipios de Tlaxcala. Con la participación del Centro Estatal de Estudios Municipales de Tlaxcala (CEEM), México.

Vargas, M. E. E., Castillo N. M., y Zizumbo V. L. 2011. Turismo y Sustentabilidad Una reflexión epistemológica. Estudios y Perspectivas en Turismo. 20, $706-721$. Obtenido de http:// www.estudiosenturismo.com.ar/PDF/V20/N03/v20n3a10.pdf

Virgen Aguilar, Carlos Rogelio. 2014. Turismo y desarrollo sustentable. Un acercamiento al estudio del Turismo. ISBN: 978607-9383-36-7. TRAUCO Editorial. Recuperado de. http:// amestur.org/wp-content/uploads/2015/03/Turismo-y-desarrollo-sustentable_digital.pdf

Zaragoza-Caballero, S. 2012. Macrolampis palaciosi sp. nov. (Coleoptera: Lampyridae: Photininae), Tlaxcala, México. Dugesiana 19(2): 117-121. Recuperado de: http://dugesiana.cucba. udg.mx/dugesiana_dic2012/19_117.pdf). 